Article

\title{
An Input-Output Assessment of Water Productivity in the Castile and León Region (Spain)
}

\section{Carlos Dionisio Pérez Blanco ${ }^{1, *}$ and Thomas Thaler ${ }^{2}$}

1 Fondazione Eni Enrico Mattei and Centro Euro-Mediterraneo sui Cambiamenti Climatici, Isola di San Giorgio Maggiore n.8, Venice 30124, Italy

2 Flood Hazard Research Centre, Middlesex University, North London Business Park, Oakleigh Road South, New Southgate, London N11 1NP, UK; E-Mail: t.thaler@mdx.ac.uk

* Author to whom correspondence should be addressed; E-Mail: dionisio.perez@feem.it; dionisio.perez@cmcc.it; Tel.: +39-041-270-0411; Fax: +39-041-270-0412.

Received: 9 December 2013; in revised form: 10 March 2014 / Accepted: 1 April 2014 /

Published: 14 April 2014

\begin{abstract}
The failure in the past to acknowledge the limits of water supply and to decouple economic development from water demand has resulted in a water dependent growth model currently threatened by increasing scarcity and droughts. Consequently, there is now an urgent need to use sparse water resources in a more sustainable and efficient way. This demands a comprehensive understanding of water productivity and the linkages among economic sectors to illustrate the tradeoffs in water reallocations from productive sectors to priority uses (household and urban uses). This paper develops a methodology based on the Hypothetical Extraction Method to estimate inter-temporal direct and indirect water productivity. The method is applied to the Spanish region of Castile and León. Results confirm the existence of a relevant water productivity gap between the agriculture (the largest water consumer) and that of the other sectors, which are nonetheless largely dependent on the agricultural output (and thus, on agricultural water demand). Results also show that Gross Domestic Product (GDP) growth, say about $1 \%$, results in an increase of indirect water productivity in the manufacturing blocks $(0.49 \%$ and $0.38 \%)$, energy and water $(0.39 \%)$ and service blocks $(0.41 \%)$, providing evidence of the existence of a Verdoorn's Law for water.
\end{abstract}

Keywords: environmental input-output modeling; Verdoorn's Law; water management; water productivity 


\section{Introduction}

Water is a scarce input necessary for the production of many valuable goods and services and should be managed accordingly. However, water policy in European Union (EU) countries up to this date has failed to consider water as an economic good and has focused instead on guaranteeing the supply of this resource at subsidized prices. Under this paradigm, population growth and the improvement of living standards brought about by development have driven water demand up and the pressures over water resources have escalated. Consequently, water is now overexploited in many areas across the globe [1]. As water has become scarcer, policy making has been reactive and incremental, and conventional supply policies, instead of being replaced, have been reinforced. Surprise and crisis are now more regular occurrences and there is an increasing need worldwide to manage water resources "better" $[2,3]$.

Alternative policies, comprising command-and-control instruments (e.g., Drought Management Plans), technical alternatives (e.g., Irrigation Modernization Plans) and economic instruments (e.g., water pricing, water markets, insurance, buyback of agricultural water use rights) have been explored to address this challenge [4-8]. Ultimately, all these policies aim towards the attainment of a strategic reallocation of water resources that achieves the collectively agreed goals of water policy without impairing, or alternatively minimizing, the impact on the output of the productive activities that rely upon this input. Therefore, what is crucial in their design is to identify the productive activities in which potential water use restrictions may have a lower impact on the economy, in the short (e.g., Drought Management Plans) and in the medium-long term (e.g., Irrigation Modernization Plans). This demands a comprehensive understanding of Water Productivity (WP) dynamics that integrates the relevant linkages among productive sectors. The objective of this paper is to improve this understanding in order to better inform policy makers in the development of new water policies.

We can safely define WP as the output of a given activity (in economic terms, if possible) divided by a measure of water input [9]. There is a vast array of techniques and methodologies available to estimate WP, ranging from intrasectoral to intersectoral analyses. In the following lines, we present some relevant studies to illustrate the advances in this field and we show how our model may contribute to fill in a gap in the literature through the development of an intersectoral and inter-temporal Input-Output (IO) model.

As irrigation is by and large the main water consumer worldwide, most of the studies available refer to WP in agriculture either from an agronomic, economic or hydrologic perspective, or a combination of them (intrasectoral models). A very fruitful research field relies on the water balance concept considering different spatial boundaries [10-14]. More recently, the rise of geo-referenced systems and remote sensing has permitted the development of a new series of studies based on spatial models [15-19]. Although rare, there is also research on WP in the secondary and tertiary sectors [20,21]. All this research allows a detailed understanding of the water use within a particular sector, but it only offers an intrasectoral assessment of WP (apparent/direct WP) that excludes the analysis of forward and backward linkages among sectors and therefore is insufficient to assess the potential for intersectoral water reallocations.

The problem of how to better allocate the scant water resources available in an economy among competing uses requires an intersectoral assessment of WP. IO models have the potential to address 
this issue. IO models have been traditionally used to assess direct (observed) and indirect water uses (induced) in different EU regions [22-24]. More recently, these models have been adapted to assess the economic impact of alternative water policies [25-27].

This body of literature offers an insightful approach to WP assessment for all the sectors in the economy considering different scenarios. In addition, it makes possible the estimation and comparison of both apparent/direct WP (which is measured in the intrasectoral models above) and indirect WP (missing in the intrasectoral models). Direct WP is obtained as the ratio of the economic output to the observed water use in the sector, while indirect WP is obtained as the ratio of the economic output to the amount of water consumption induced by the sector. That is to say, the latter includes in the denominator the water that would not be used in the economy if that sector was to be removed from the economy. This information is of great importance to assess the actual impact on the economy of policies constraining water use over specific productive sectors.

Although WP assessments have become increasingly complex over time, from intrasectoral to intersectoral studies, simultaneous intersectoral and inter-temporal IO models are not available yet. IO models are static and do not assess WP dynamics. This is largely owed to the lack of continuous data series [28]. Nonetheless, this has changed recently as environmental satellite accounts (including water accounting) and IO tables have become regularly available in some regions, such as the Castile and León Region in Spain. New statistical data now makes possible not only an intersectoral but also an inter-temporal assessment of WP. This is useful for comparing the performance of different sectors of the economy over time.

This paper aims to shed light over the inter-temporal problem of how to efficiently assign scarce water resources among productive sectors. The study applies the Hypothetical Extraction Method (HEM) $[29,30]$ to the particular case of water resources and obtains annual indirect and direct WP in the Spanish region of Castile and León (CL) for a seven-year period (2000-2006) [31]. HEM has been used previously in the literature to measure the intersectoral linkages of inputs such as energy (see for example [32]). The paper is structured as follows: Section 2 introduces the Case Study area, the Castile and León Region in Spain; Section 3 describes the HEM applied to water; Section 4 presents the results, including direct and indirect WP values for urban and irrigation water and the Verdoorn's Law for water; Section 5 discusses the implications of the findings for current policy making and concludes the paper.

\section{The Case Study Area: The Castile and León Region (Spain)}

CL is at the same time the largest region in Spain $\left(94,223 \mathrm{~km}^{2}, 18.7 \%\right.$ of the Spanish territory) and one of the most depopulated regions in Europe (26.6 people per $\mathrm{km}^{2}$ ) [33]. The structure of the CL's economy is similar to that of the Spanish economy as a whole. Industry, construction and the tertiary sector have a similar composition in CL and in Spain and their weights over regional and national GDP, although slightly smaller in the case of CL, have also showed a similar evolution during the last decades. However, CL has been traditionally and is still today an agrarian region with classic agrarian periphery socio-economic problems, namely, depopulation and low income.

In 2006, agriculture represented $6.6 \%$ of the GDP and $10.2 \%$ of total employment in CL, more than doubling the Spanish shares $(2.7 \%$ of the GDP and $4.4 \%$ of the employment) and well above the 
EU-28 shares (1.7\% and 5.7\%). More than half (52\%) of CL surface is devoted to agricultural uses (Spain: 52\%; EU-27: 43\%). Prevailing agro-ecosystems in CL are cereal landscapes and irrigated areas that produce relatively low agrarian incomes [34,35]. Irrigation is the main water user and represents $92 \%$ of total consumption in the region or $98 \%$ excluding non-consumptive uses [36].

Eighty-two percent of the CL Region is located inside the Duero River Basin (DRB) boundaries. Since the 1990s, the DRB has experienced the most intense, widespread and lasting droughts in a century [36]. Moreover, average water availability has fallen and this trend is expected to continue [36,37], thus threatening all water uses including priority environmental and household supply [36]. Authorities have reacted to these challenges in two ways. First, the regional authority has regulated drought response through a Drought Management Plan that decreases water availability for productive uses under drought events [36]. Unlike other Drought Management Plans that clearly specify the water restrictions to be applied for every sector under each drought threshold, the DRB Drought Management Plan offers a considerable degree of flexibility [36]. Therefore, this new regulation may have a different impact on regional GDP depending on the sectors affected by water restrictions [25]. Second, regarding water scarcity, the recently approved Duero River Basin Management Plan established a set of guidelines (potentially including economic instruments, command-and-control policies and technical alternatives) to restore environmental services that will likely demand a permanent restriction in water use in some productive activities [34].

Although with a different time scope (short run in the case of the Drought Management Plan and medium-long run in the case of the River Basin Management Plan), both regulations determine a reallocation of water resources from productive activities to priority uses, which include environmental uses, household demand and under particular junctures industrial uses and energy production [34,36]. This demands a profound understanding of the impacts of permanent and temporary reallocation policies over productive activities, and thus of WP dynamics and the linkages among economic sectors.

\section{Data and Methods}

This study uses the Hypothetical Extraction Method (HEM) to combine Water Satellite Accounts (WSA) with IO symmetric tables in order to estimate intersectoral water flows and from here their corresponding direct and indirect WPs [29,30,32,38]. We repeat the process for each one of the seven years of the period considered.

This paper starts from an IO model where the production of an economy comprising $n$ sectors is described as follows $[29,30,38]$ :

$$
x=\mathrm{A} x+y=\left(\begin{array}{cc}
\mathrm{A}_{s, s} & \mathrm{~A}_{s,-s} \\
\mathrm{~A}_{-s, s} & \mathrm{~A}_{-s,-s}
\end{array}\right)\left(\begin{array}{c}
x_{s} \\
x_{-s}
\end{array}\right)+\left(\begin{array}{c}
y_{\mathrm{s}} \\
y_{-s}
\end{array}\right)
$$

Being $x=x_{i}$ the production vector or total output, $y=y_{i}$ the vector of final demands (i.e., the final output of the economy [39]) and $\mathrm{A}=\mathrm{A}_{i j}$ the matrix of technical coefficients. The economy can be split into blocks comprising one or more sectors. The subscript $s$ refers to a specific block, and the subscript $-S$ to the remaining blocks of the economy. Alternatively, Equation (1) can be formulated as follows [29,30,38]: 


$$
\begin{gathered}
x=(\mathrm{I}-\mathrm{A})^{-1} y=\left(\begin{array}{cc}
\Delta_{s, s} & \Delta_{s,-s} \\
\Delta_{-s, s} & \Delta_{-s,-s}
\end{array}\right)\left(\begin{array}{c}
\mathrm{y}_{s} \\
\mathrm{y}_{-s}
\end{array}\right) \\
\text { where: }\left(\begin{array}{cc}
\Delta_{s, s} & \Delta_{s,-s} \\
\Delta_{-s, s} & \Delta_{-s,-s}
\end{array}\right)=\left(\begin{array}{cc}
\left(\mathrm{I}-\mathrm{A}_{s, s}\right)^{-1} & \left(\mathrm{I}-\mathrm{A}_{s,-s}\right)^{-1} \\
\left(\mathrm{I}-\mathrm{A}_{-s, s}\right)^{-1} & \left(\mathrm{I}-\mathrm{A}_{-s,-s}\right)^{-1}
\end{array}\right)
\end{gathered}
$$

Being $(\mathrm{I}-\mathrm{A})^{-1}$ the Leontief inverse. The HEM measures the impact of every block (namely, $s$ ) by comparing the production vector of that economy with $(\mathrm{X} x)$ and without $\left(x^{*}\right)$ that block, which are a function of the technical coefficients with (AA) and without $\left(\mathrm{A}^{*}\right)$ that block and the final demands with $(\mathrm{Y} y)$ and without $\left(y^{*}\right)$ that block, respectively. The production of the economy in which a given block $(s)$ is extracted is described as follows [29,30,38]:

$$
x^{*}=\left(\mathrm{I}-\mathrm{A}^{*}\right)^{-1} y^{*}=\left(\begin{array}{cc}
\left(\mathrm{I}-\mathrm{A}_{s, s}\right)^{-1} & 0 \\
0 & \left(\mathrm{I}-\mathrm{A}_{-s,-s}\right)^{-1}
\end{array}\right)\left(\begin{array}{c}
y_{s} \\
y_{-s}
\end{array}\right)
$$

The change in production is obtained as the difference between $\mathrm{X} x$ (Equation (2)) and $x^{*}$ (Equation (4)) and shows the effect of the block $s$ over the remaining blocks of the economy $[29,30,38]$ :

$$
x-x^{*}=\left(\begin{array}{cc}
\mathrm{C}_{s, s} & \mathrm{C}_{s,-s} \\
\mathrm{C}_{-s, s} & \mathrm{C}_{-s,-s}
\end{array}\right)\left(\begin{array}{c}
y_{s} \\
y_{-s}
\end{array}\right)
$$

Every block has four separate effects over the economy: an internal effect, a mixed effect, an external or net backward linkage and an external or net forward linkage. The internal effect of the block $s\left(I E_{s}\right)$ represents the effect of the goods produced, sold and purchased inside the sector $s$ to obtain its final demand $y_{s}$. The mixed effect $\left(M E_{s}\right)$ measures the impact of the products sold by the block $s$ to other blocks and later re-purchased to produce $y_{s}$. The net backward linkage $\left(N B L_{s}\right)$ represents the direct and indirect requirements of the sector $s$ from the rest of the economy to obtain $y_{s}$, namely the "imports" of the sectors. Finally, the net forward linkage $\left(N F L_{S}\right)$ represents the direct and indirect requirements of the rest of the economy from the sector $s$ to obtain $y_{-s}$, namely the "exports" of the sectors [30]:

$$
\begin{gathered}
I E_{s}=c^{\prime}\left(\mathrm{I}-\mathrm{A}_{s, s}\right)^{-1} \mathrm{y}_{s} \\
M E_{s}=c^{\prime}\left[\Delta_{s, s}-\left(\mathrm{I}-\mathrm{A}_{s, s}\right)^{-1}\right] y_{s} \\
N B L_{s}=c \Delta_{-s, s} y_{s} \\
N F L_{s}=c^{\prime} \Delta_{s,-s} y_{-s}
\end{gathered}
$$

where $c^{\prime}$ denotes the vector $(1, \ldots, 1)$.

Vector $c^{\prime}$ is now replaced by a vector of unitary inputs of water $\left(w^{\prime}\right)$ calculated as the quotient of water use in every sector $s$ (available in the WSA) to its final demand $y_{s}$ (or final output, available in the IO symmetric tables) [22,32]. With this information it is possible to obtain the four effects over the economy of the block $s$, but this time referred to the amount of water embodied in the part of the production process that the different effects represent. Now the internal effect $\left(I E w_{S}\right)$ is the water consumed exclusively inside the block $s$; the mixed effect $\left(M E w_{s}\right)$ is the water consumed in the block $s$, then used as an input in other block/s and again used as an input in the block $s$; the net backward 
linkage $\left(N B L w_{s}\right)$ is the water originally used in other blocks than $s$ and then "imported" and used in $s$ to generate the final demand; and the net forward linkage $\left(N F L w_{S}\right)$ is the water originally used in the block $s$ and then "exported" and used in other block/s to generate their final demand:

$$
\begin{gathered}
I E w_{s}=w^{\prime}\left(\mathrm{I}-\mathrm{A}_{s, s}\right)^{-1} y_{s} \\
M E w_{s}=w^{\prime}\left[\Delta_{s, s}-\left(\mathrm{I}-\mathrm{A}_{s, s}\right)^{-1}\right] y_{s} \\
N B L w_{s}=w \Delta_{-s, s} y_{s} \\
N F L w_{s}=w^{\prime} \Delta_{s,-s} y_{-s}
\end{gathered}
$$

These effects are subsequently added into two groups in order to obtain the vertically integrated effect and the direct effect. The direct effect $\left(D E_{s}\right)$ stems from direct consumption and is the result of the aggregation of the mixed effect, internal effect and net forward linkages of the block $s$ (i.e., the water directly consumed by the block). The ratio between the final demand $\left(y_{s}\right)$ and the direct effect $\left(D E_{s}\right)$ of that block is its direct water productivity $(D W P)$, namely, the quotient of final demand to observed water uses (equivalent to apparent productivity) [29]:

$$
\begin{gathered}
D E_{s}=I E w_{s}+M E w_{s}+N F L w_{s} \\
D W P=\frac{y_{s}}{D E_{s}}
\end{gathered}
$$

The vertically integrated effect $\left(V I E_{S}\right)$ stems from indirect consumption and is the result of the aggregation of the internal effect, mixed effect and the net backward linkages (i.e., the water that would not be consumed in the economy if blocks was to be removed from the economy, or alternatively the water consumption induced by blocks). The ratio between the final demand $\left(y_{s}\right)$ and the vertically integrated effect $\left(V I E_{s}\right)$ of a given block is its indirect water productivity $(I W P)$, namely, the quotient of final demand to water use induced by this block [30].

$$
\begin{gathered}
V I E_{s}=I E w_{s}+M E w_{s}+N B L w_{s} \\
I W P=\frac{y_{s}}{V I E_{s}}
\end{gathered}
$$

For the assessment of WP, this study uses data from the WSA and the IO symmetric tables (product-by-product, constant prices) for CL. WSA are a statistical source yearly available in Spain since 1997 that provide information on the amount of water used by every economic sector [40]. On other hand, symmetric tables are offered intermittently by national and regional institutes of statistics; however, CL Institute of Statistics has been yearly supplying symmetric IO tables since 2000 [41]. As a result, both symmetric tables and WSA have been available simultaneously for every year during the period 2000-2006.

WSA offer information on water use disaggregated in 24 productive sectors for different types of water. This paper distinguishes between irrigation (92\% of total water demand, $98 \%$ excluding non-consumptive uses such as hydropower and power plant cooling water demand) and the sum of drinkable and non-drinkable water (to which this paper will refer as urban water, representing the remaining $8 \%$ of the total water demand and $2 \%$ excluding non-consumptive uses). Therefore, the vector $w^{\prime}$ (the quotient of water use in every sector $s$ to its final demand $y_{s}$ ) is obtained for both 
irrigation and urban water, and accordingly DWP and IWP are obtained for irrigation and urban water separately. On the other hand, the IO symmetric tables for CL offer economic information disaggregated in 58 sectors. In this paper, all the different sectors in the WSA and IO tables are put into the seven homogeneous blocks described in Table $1[22,38]$.

Table 1. Block configuration and water demand ${ }^{1}$ by block in the Castile and León Region, 2000-2006.

\begin{tabular}{|c|c|c|c|c|c|c|c|c|}
\hline \multirow{2}{*}{ Block } & \multirow{2}{*}{ Economic sector } & \multicolumn{7}{|c|}{ Direct water consumption (thousand $\mathrm{m}^{3} /$ year) } \\
\hline & & 2000 & 2001 & 2002 & 2003 & 2004 & 2005 & 2006 \\
\hline $\begin{array}{l}\text { Block } \\
1(\mathrm{~B} 1)\end{array}$ & $\begin{array}{l}\text { Agriculture, livestock, hunting, } \\
\text { forestry and fishing }\end{array}$ & $2,079,842$ & $1,917,250$ & $2,101,940$ & $2,235,375$ & $2,356,046$ & $2,317,267$ & $2,171,866$ \\
\hline $\begin{array}{l}\text { Block } \\
2 \text { (B2) }\end{array}$ & $\begin{array}{l}\text { Extraction of energy products, } \\
\text { extraction of other mineral } \\
\text { products, oil refining and nuclear } \\
\text { fuels, water collection, } \\
\text { purification and distribution and } \\
\text { energy, gas and water production } \\
\text { and distribution }\end{array}$ & 7,451 & 7,060 & 7,139 & 8,312 & 6,794 & 6,460 & 4,622 \\
\hline $\begin{array}{l}\text { Block } \\
3 \text { (B3) }\end{array}$ & Food, drinks and tobacco & 3,693 & 3,586 & 3,939 & 4,543 & 3,954 & 5,206 & 4,701 \\
\hline $\begin{array}{l}\text { Block } \\
4 \text { (B4) }\end{array}$ & $\begin{array}{l}\text { Textile and clothing, leather and } \\
\text { footwear, timber and cork, paper } \\
\text { and publishing and other non- } \\
\text { metallic mineral products } \\
\text { industries }\end{array}$ & 1,338 & 1,359 & 1,391 & 1,946 & 1,533 & 1,443 & 970 \\
\hline $\begin{array}{l}\text { Block } \\
5 \text { (B5) }\end{array}$ & $\begin{array}{l}\text { Chemicals, rubber and plastic } \\
\text { materials transformation, } \\
\text { metallurgy and manufacture of } \\
\text { metal products, machinery and } \\
\text { mechanical equipment, electric } \\
\text { and electronic material, transport } \\
\text { material and diverse } \\
\text { manufacturing industries }\end{array}$ & 7,979 & 7,909 & 8,779 & 9,920 & 8,557 & 8,012 & 5,538 \\
\hline $\begin{array}{l}\text { Block } \\
6(\mathrm{~B} 6)\end{array}$ & Construction & 1,309 & 1,453 & 1,538 & 1,627 & 1,395 & 1,550 & 1,109 \\
\hline $\begin{array}{l}\text { Block } \\
7 \text { (B7) }\end{array}$ & $\begin{array}{c}\text { Public sanitation, public } \\
\text { Administration and other service } \\
\text { sector activities }\end{array}$ & 24,017 & 25,288 & 25,634 & 27,653 & 21,232 & 22,459 & 16,840 \\
\hline $\begin{array}{c}\text { All } \\
\text { blocks }\end{array}$ & All economic sectors & $2,125,628$ & $1,963,904$ & $2,150,360$ & $2,289,376$ & $2,399,510$ & $2,362,397$ & $2,214,380$ \\
\hline
\end{tabular}

Note: ${ }^{1}$ Only consumptive uses. Irrigation and urban water. Source: [40].

\section{Results}

We obtain IWP (Tables 2 and 3) and DWP (Tables 4 and 5) for every single block and year during the period 2000-2006, for both urban and irrigation water. All WP values are shown in constant prices (real WP). 
IWP values (Table 2) in the year 2006 are inflated as a result of the extreme drought that suffered Spain and particularly the DRB since mid-2005, the most intense ever recorded in the basin [34]. Water supply restrictions significantly increased water efficiency and IWP. The opposite can be said for the relatively water abundant period 2002-2003. In any case and in spite of these anomalies, a clear trend for IWP in every block and water type (irrigation, urban) can be inferred for the period analyzed.

Table 2. Indirect Water Productivity (IWP) in the Castile and León Region, 2000-2006 $\left(€ / \mathrm{m}^{3}\right.$, constant prices), irrigation water.

\begin{tabular}{cccccccc}
\hline Block/year & $\mathbf{2 0 0 0}$ & $\mathbf{2 0 0 1}$ & $\mathbf{2 0 0 2}$ & $\mathbf{2 0 0 3}$ & $\mathbf{2 0 0 4}$ & $\mathbf{2 0 0 5}$ & $\mathbf{2 0 0 6}$ \\
\hline B1 & 1.81 & 1.81 & 1.72 & 1.58 & 1.67 & 1.46 & 1.92 \\
B2 & 186.46 & 193.91 & 172.6 & 172.62 & 179.45 & 141.38 & 145.42 \\
B3 & 4.06 & 4.27 & 3.98 & 3.74 & 3.99 & 3.35 & 3.73 \\
B4 & 26.84 & 29.1 & 26.09 & 24.97 & 29.04 & 22.98 & 24.32 \\
B5 & 103.19 & 104.41 & 95.38 & 93.53 & 99.6 & 81.11 & 91.55 \\
B6 & 77.24 & 82.07 & 72.92 & 67.79 & 72.21 & 55.29 & 57.73 \\
B7 & 63.72 & 66.82 & 60.42 & 56.34 & 59.81 & 50.07 & 55.79 \\
\hline
\end{tabular}

Note: Authors' elaboration from [40,41].

Table 3. Indirect Water Productivity (IWP) in the Castile and León Region, 2000-2006 $\left(€ / \mathrm{m}^{3}\right.$, constant prices $)$, urban water.

\begin{tabular}{cccccccc}
\hline Block/year & $\mathbf{2 0 0 0}$ & $\mathbf{2 0 0 1}$ & $\mathbf{2 0 0 2}$ & $\mathbf{2 0 0 3}$ & $\mathbf{2 0 0 4}$ & $\mathbf{2 0 0 5}$ & $\mathbf{2 0 0 6}$ \\
\hline B1 & 169.06 & 148.15 & 129.08 & 112.51 & 137.32 & 124.15 & 168.72 \\
B2 & 250.75 & 269.39 & 272.46 & 237.76 & 295.46 & 292.79 & 458.47 \\
B3 & 265.84 & 252.38 & 220.72 & 199.14 & 243.78 & 213.27 & 247.31 \\
B4 & 557.77 & 585.93 & 557.41 & 471.81 & 615.26 & 598.05 & 802.64 \\
B5 & 531.68 & 526.79 & 501.64 & 459.93 & 562.00 & 570.78 & 822.52 \\
B6 & 869.88 & 869.99 & 826.12 & 732.37 & 878.23 & 807.52 & 1088.99 \\
B7 & 701.30 & 685.85 & 671.72 & 623.25 & 810.61 & 788.63 & 1065.41 \\
\hline
\end{tabular}

Note: Authors' elaboration from [40,41].

Irrigation water (Table 2) is directly demanded by agriculture. The remaining blocks demand irrigation water only indirectly through the significant backward linkages that they have with agriculture. The observed IWP in the CL Region is low and lower than the values available for other Spanish regions [22-24]. Moreover, IWP in the agricultural sector shows a negative trend, thus dragging IWP in the other sectors of the economy. This means that most of the water being used in the economy is employed with a low and decreasing efficiency. This happens in spite of the large investments in irrigation modernization in the area as part of the National Irrigation Modernization Plan that started in 2002. In fact, although the National Irrigation Modernization Plan put into practice the existing resource saving technical alternatives, water governance and institutional capacity were not improved accordingly. As a result, the potential for water saving through the development of more efficient irrigation devices was largely used to increase the irrigated area [42], thus showing no positive impact on IWP (nor in DWP).

In the case of urban water (Table 3), there are two clearly differentiated trends. In the primary sector (B1) and in the food industry (B3), IWP is low and shows a negative trend. IWP low value in 
B3 is a consequence of its dependency on B1, which results in a high indirect demand (high net backward linkage) from low productive B1. The construction sector (B6) shows a constant trend for IWP [43] (until the 2005-2006 drought).

On other hand, the tertiary sector (B7), manufacturing industry (B4 and B5) and the energy and water block (B2) show a significant and continued increase of IWP along the period: IWP increases by $15.5 \%$ in $\mathrm{B} 2,6.8 \%$ in $\mathrm{B} 4,7.1 \%$ in $\mathrm{B} 5$ and $11.7 \%$ in $\mathrm{B} 7$ in the period $2000-2005$. At the same time, GDP also shows significant growth rates for these sectors $(31.6 \%, 17.9 \%, 18.2 \%$ and 28.5\%) [33]. This empirical result may be regarded as a Verdoorn's Law for water: faster growth in output increases productivity due to increasing returns in certain blocks of the economy prone to technological improvements and efficiency gains (such as the manufacturing industry). To the best of our knowledge, this is the first time that the Verdoorn's Law for Water is assessed in the literature. Original research based on labor productivity [44,45] estimated that changes in the volume of production, say about $1 \%$, tend to be associated with an average increase in input productivity (in those cases, labor) between $0.45 \%$ and $0.484 \%$, with extreme values of 0.41 in the UK and 0.57 in the US. Subsequent estimations of the law found figures close to this value. In our case, a $1 \%$ increase in the volume of production results in an average increase of IWP in the selected blocks of $0.49 \%$ (B2), $0.38 \%$ (B4), $0.39 \%$ (B5) and $0.41 \%$ (B7) in the period 2000-2005. Longer series are needed to obtain concluding evidence; nonetheless, these results suggest the existence of a Verdoorn's law for water in these economic sectors.

DWP values largely differ from IWP. In the case of irrigation water (Table 4), DWP method does not consider the water indirectly demanded by other blocks and consumed in agriculture. As a result, DWP underestimates WP in agriculture as compared to the preferred IWP method by $26 \%-31 \%$. DWP in the rest of the blocks of the economy equals 0 , since backward linkages are not considered in this method.

Table 4. Direct/apparent Water Productivity (DWP) in the Castile and León Region, 2000-2006 (€/ $\mathrm{m}^{3}$, constant prices), irrigation water.

\begin{tabular}{cccccccc}
\hline Block/year & $\mathbf{2 0 0 0}$ & $\mathbf{2 0 0 1}$ & $\mathbf{2 0 0 2}$ & $\mathbf{2 0 0 3}$ & $\mathbf{2 0 0 4}$ & $\mathbf{2 0 0 5}$ & $\mathbf{2 0 0 6}$ \\
\hline B1 & 0.56 & 0.55 & 0.52 & 0.47 & 0.51 & 0.4 & 0.51 \\
B2 & 0 & 0 & 0 & 0 & 0 & 0 & 0 \\
B3 & 0 & 0 & 0 & 0 & 0 & 0 & 0 \\
B4 & 0 & 0 & 0 & 0 & 0 & 0 & 0 \\
B5 & 0 & 0 & 0 & 0 & 0 & 0 & 0 \\
B6 & 0 & 0 & 0 & 0 & 0 & 0 & 0 \\
B7 & 0 & 0 & 0 & 0 & 0 & 0 & 0 \\
\hline
\end{tabular}

Note: Authors' elaboration from [40,41].

In the case of urban water demand (Table 5), DWP method largely overestimates WP in the water-importing blocks (B3, B4, B5, B6 and B7) and underestimates it in the water-exporting blocks (B1 and B2) as compared to IWP. DWP method supports the existence of increasing returns in water for blocks B2, B4, B5 and B7, but also for B6. In this case, the construction sector (B6) shows this positive relationship as the negative effect of its net backward linkages with low WP blocks is replaced by the positive effect of its net forward linkages with high WP blocks. 
Table 5. Direct/apparent Water Productivity (DWP) in the Castile and León Region, 2000-2006 (€/ $\mathrm{m}^{3}$, constant prices $)$, urban water.

\begin{tabular}{cccccccc}
\hline Block/year & $\mathbf{2 0 0 0}$ & $\mathbf{2 0 0 1}$ & $\mathbf{2 0 0 2}$ & $\mathbf{2 0 0 3}$ & $\mathbf{2 0 0 4}$ & $\mathbf{2 0 0 5}$ & $\mathbf{2 0 0 6}$ \\
\hline B1 & 57.86 & 55.48 & 46.20 & 42.25 & 54.81 & 43.21 & 49.07 \\
B2 & 144.80 & 145.56 & 156.37 & 142.80 & 174.41 & 185.96 & 338.47 \\
B3 & 1030.70 & 921.67 & 860.56 & 952.85 & 982.45 & 832.67 & 952.22 \\
B4 & 1044.29 & 1506.13 & 1539.60 & 843.55 & 1374.38 & 1701.20 & 2727.97 \\
B5 & 677.72 & 734.66 & 695.81 & 604.52 & 808.37 & 855.78 & 1295.45 \\
B6 & 3421.15 & 2635.68 & 2733.49 & 3679.54 & 3846.88 & 4012.62 & 6525.80 \\
B7 & 639.89 & 650.63 & 704.48 & 693.59 & 955.72 & 978.06 & 1418.25 \\
\hline
\end{tabular}

Note: Authors' elaboration from [40,41].

\section{Discussion and Conclusions}

This paper uses the HEM applied for water to estimate WP in the production of goods and services in the CL Region during the period 2000-2006. Using the internal effect, the mixed effect, the net forward linkage and the net backward linkage values and the concepts of vertically integrated and direct consumption this paper assesses direct and indirect WP in the different sectors of the economy for irrigation water and drinkable and non-drinkable water (urban water). It is argued that apparent/direct WP is not the appropriate measure to obtain WP, as it misses the relevant links that exist among sectors and that explain observed water demand. To the best of our knowledge, the model presented in this paper constitutes the first IO analysis on WP combining intersectoral and inter-temporal data. The results obtained with this methodology may be used to draw relevant conclusions for policy making in increasingly water stressed and drought exposed regions.

Water saving policies need to have a strong focus on irrigation. Agriculture is the main water consumer worldwide, and in the CL Region it shows a low and decreasing WP that drags the remaining sectors of the economy (see Table 2) [22-24]. With only a few exceptions in small agricultural areas where water availability is very low and agricultural income is very high [46], it would be unrealistic to expect that agricultural water use may reach a WP level comparable to those of other economic sectors. Therefore, a large potential for water saving may be found here and several proposals to limit water demand in agriculture have been advanced. This is the case of command-and-control policies such as Drought Management Plans, which establish temporary irrigation restrictions during drought events and are a key element of the EU strategy against droughts [4]. However, Drought Management Plans have been often criticized because they do not address the incentives behind increasing water demand [46]. Also, technical alternatives such as the National Irrigation Modernization Plan have been explored and implemented in the CL Region, although with disappointing results: in this case, the opportunity to save water from the enhanced technical efficiency was largely used to increase the irrigated surface $[42,47]$. This is coherent with the findings obtained elsewhere by $[8,48,49]$. This is not to say that technical improvements should be disregarded: there is still significant leeway for further savings if best available technologies are used. However, converting higher technical efficiency (i.e., the effectiveness with which inputs are used to produce an output) into higher allocative efficiency (i.e., a more efficient allocation of resources within markets) is not straightforward. 
In this context, water policy should focus on taking the advantage of regulatory instruments and technical efficiency gains to achieve collectively agreed goals through a better governance of water resources, for example through the use of economic instruments that allow an internalization of the costs of the resource and encourage a higher technical and allocative efficiency and WP (e.g., water pricing, water trading) [50-52].

In any case, any water saving policy needs to consider that most of the water that is directly demanded by agriculture is used to produce goods that supply other sectors of the economy. This paper contributes to shed light upon this relevant issue and estimates the indirect productivity of irrigation water. In the case of CL, the net backward linkages ("imports") of the remaining blocks from the agricultural block (B1) represent between $69 \%$ and $73.5 \%$ of irrigation water demand along the period 2000-2006. Therefore, any policy to reduce the volume of water used by agriculture, even in the less water productive areas, may significantly affect other sectors of the economy (such as the food industry or the service sector, both essential in the CL economy). For example, during the 2005-2006 drought event in CL, water restrictions reduced agricultural GDP by $6.2 \%$ and as a result production in the food industry fell by more than 3\% [33]. If the new Drought Management Plan had been applied, restrictions over irrigation water supply would have been presumably larger and thus would have had a more negative impact on both sectors, which together represent $14 \%$ of the employment and $20.1 \%$ of the GVA in the region [33,36].

Consequently, although a reduction in water use in the agricultural sector would result in an overall WP increase, it would have also adverse effects over production and employment in the rest of the economy in the short run (e.g., through restrictions during drought events as considered in Drought Management Plans). In the case of medium to long run irrigation restrictions, such as permanent water reallocations through the public buyback of agricultural water use rights as in the Murray-Darling Basin Plan in Australia [50], the dependence of some sectors on the agricultural output would likely result in either a reduction of exports (the most likely case in the CL Region, a net exporter of agricultural products) or a substitution of local products by imports (noteworthy, this may increase the costs and in some sectors such as the agro industry this substitution may not be possible due to high transportation costs) [33]. Thus, the water scarcity problem would be transformed into a balance of payments problem.

In addition, agriculture still has a fundamental and strategic role in terms of food supply independence, habitat and landscape protection, soil conservation, carbon dioxide sequestration, biodiversity conservation and food security [53]. Moreover, the transaction costs of implementing these policies may be prohibitive [54,55]. These spin-offs are outside our financial analysis but are undoubtedly a relevant factor to understand agricultural policies in the EU and worldwide and may result in a reluctance to implement significant water restrictions in this sector.

Because of the negative impact on the economy (estimated in this paper) and due to the high transaction costs and the strategic role of agriculture, policy makers have been traditionally unwilling to reduce and even to limit agricultural water use. However, unless current water demand trends are reverted, this situation will ultimately become unsustainable as a result of the river basin closure, the anthropogenic process that is manifested when water supply cannot meet the commitments to fulfil demand in terms of water quality and quantity within the basin during a given period of time. Experience shows that eventually the opportunity costs of inaction will be perceived as prohibitive, 
and water restrictions and reallocations will be necessary. In this context, our analysis may provide relevant insights for policy makers. Moreover, if transaction costs may be successfully addressed by institutions, these results may serve to guide a smooth transition towards a sustainable water use, which is more economically efficient than abrupt reactions [54,55].

In the meantime, though, an alternative solution has been the implementation of water restrictions in the urban sector during droughts $[34,36]$, even if the potential for water saving here is marginal and the impact on markets is larger as compared to irrigation. In any case, this paper also shows that relevant increases in WP of urban water (drinkable and non-drinkable water) can be obtained along with GDP growth, thus creating an opportunity to stabilize urban water use without impairing GDP growth. Evidence of the existence of a Verdoorn's Law for water has been found in CL for the energy and water block (B2), manufacturing (B4 and B5) and the service sector (B7), which together represent $76 \%-78 \%$ of CL's GDP in the period considered and a decreasing share of indirect urban water consumption (from $66.7 \%$ in 2000 to $56.1 \%$ in 2006). Although urban water means a minor fraction of total water demand ( $8 \%$ in CL), this result shows that economic growth is not necessarily positively correlated with higher water use. However, it should be noted that higher WP stemming from GDP growth is only an opportunity to decouple economic growth and water use that may be lost if water authorities fail to acknowledge the limits of water supply. If this is the case, higher economic output in sectors like agriculture might indeed result in higher water use [56].

In conclusion, the necessary increases in WP in the economy in order to preserve water resources without impairing GDP growth can be obtained in two different ways. In the face of a river basin closure, it is necessary to implement the necessary reforms to limit and even reduce water use in agriculture, the main water consumer worldwide and the sector with a lowest WP, avoiding a negative cascade effect over production. This goal may be attained, for example, through the progressive implementation of demand side policies that allow an internalization of the costs of the resource and encourage a higher technical and allocative efficiency and WP (e.g., water pricing, water trading). This paper contributes to this objective through the estimation of the market impact that could be expected from irrigation water restrictions (Table 2). Second, relevant GDP growth in urban areas may be attained without further additional water use as a result of the increase in WP inherent to economic growth in some sectors (B2, B4, B5 and B7). This paper obtains the relationship between GDP growth and WP. These results need to be refined when longer data series are made available, if possible identifying the impact of total factor productivity at a sectoral level, particularly in manufacturing blocks.

\section{Acknowledgments}

The research leading to these results has received funding from the EU Seventh Framework Program (FP7/2007-2013) under Grant Agreements 265213 (EPI-WATER-Evaluating Economic Policy Instruments for Sustainable Water Management in Europe) and 308438 (ENHANCEEnhancing risk management partnerships for catastrophic natural disasters in Europe) and from the Middlesex University. The authors acknowledge valuable discussion and comments from the participants at the 20th International Input-Output Conference in Bratislava in 2012, the Workshop New Directions in the Economic Analysis of Water in Lisbon in 2013 and the Envecon-Applied Environmental Economics Conference in London in 2013. 


\section{Author Contributions}

Carlos Dionisio Pérez-Blanco and Thomas Thaler designed the methodology during the stay of the former in the Flood Hazard Research Centre of the Middlesex University (UK) in 2012. Carlos Dionisio Pérez-Blanco gathered the data and conducted the literature review and Thomas Thaler applied the methodology. The paper was written with contributions from both authors.

\section{Conflicts of Interest}

The authors declare no conflict of interest.

\section{References and Notes}

1. Massarutto, A. Water pricing and irrigation water demand: Economic efficiency versus environmental sustainability. Environ. Policy Gov. 2003, 13, 100-119.

2. Molden, D.; Sakthivadivel, R. Water accounting to assess use and productivity of water. Water Resour. Dev. 1999, 15, 55-71.

3. Anderies, J.; Ryan, P.; Walker, B. Loss of resilience, crisis, and institutional change: Lessons from an intensive agricultural system in southeastern australia. Ecosystems 2006, 9, 865-878.

4. European Commission (EC). Drought Management Plan Report, Technical Report-2008-023. Available online: http://ec.europa.eu/environment/water/quantity/pdf/dmp_report.pdf (accessed on 25 February 2013).

5. Interviews, E.; Dworak, T.; Goerlach, B.; Best, A. WFD and Agriculture Linkages at the EU Level; Final Report about Incentive Water Pricing and Cost Recovery in the WFD; Elements for linking EU Agricultural and Water Policies: Berlin, Germany, 2006.

6. Albiac, J.; Playan, E.; Martinez, Y. Instruments for water quantity and quality management in the agriculture of Aragon. Int. J. Water Resour. Dev. 2007, 23, 147-164.

7. Veettil, P.C.; Speelman, S.; van Huylenbroeck, G. Estimating the impact of water pricing on water use efficiency in semi-arid cropping system: An application of probabilistically constrained nonparametric efficiency analysis. Water Resour. Manag. 2013, 27, 55-73.

8. Pfeiffer, L.; Lin, C.-Y.C. Does efficient irrigation technology lead to reduced groundwater extraction? J. Environ. Econ. Manag. 2014, 67, 189-208.

9. Playan, E.; Mateos, L. Modernization and optimization of irrigation systems to increase water productivity. Agric. Water Manag. 2006, 80, 100-116.

10. Mishra, H.S.; Rathore, T.R.; Tomar, V.S. Water use efficiency of irrigated wheat in the Tarai Region of India. Irrig. Sci. 1995, 16, 75-80.

11. Rathore, A.L.; Pal, A.R.; Sahu, R.K.; Chaudhary, J.L. On-farm rainwater and crop management for improving productivity of rain fed areas. Agric. Water Manag. 1996, 31, 253-267.

12. Bhuyian, S.I.; Sattar, M.A.; Khan, M.A.K. Improving water use efficiency in rice irrigation through wet seeding. Irrig. Sci. 1995, 16, 1-8.

13. Tuong, T.P.; Cabangon, R.J.; Wopereis, M.C.S. Quantifying flow processes during land soaking of cracked rice soils. Soil Sci. Soc. Am. J. 1996, 60, 872-879. 
14. Molden, D. Accounting for Water Use and Productivity; International Irrigation Management Institute: Colombo, Sri Lanka, 1997.

15. Van Dam, J.C.; Singh, R.; Bessembinder, J.J.E.; Leffelaar, P.A.; Bastiaanssen, W.G.M.; Jhorar, R.K.; Kroes, J.G.; Droogers, P. Assessing options to increase water productivity in irrigated river basins using remote sensing and modelling tools. Int. J. Water Resour. Dev. 2006, $22,115-133$.

16. Wesseling, J.G.; Feddes, R.A. Assessing crop water productivity from field to regional scale. Agric. Water Manag. 2006, 86, 30-39.

17. Zwart, S.J.; Bastiaanssen, W.G.M. SEBAL for detecting spatial variation of water productivity and scope for improvement in eight irrigated wheat systems. Agric. Water Manag. 2007, 89, 287-296.

18. Vazifedoust, M.; van Dam, J.C.; Feddes, R.A.; Feizi, M. Increasing water productivity of irrigated crops under limited water supply at field scale. Agric. Water Manag. 2008, 95, 89-102.

19. Cai, X.; de Fraiture, C.; Hejazi, M.I. Retrieve irrigated and rain fed crop data using general maximum entropy approach. Irrig. Sci. 2007, 25, 325-338.

20. Perez, C.D.; Gomez, C.M.; Yserte, R. Structural change and water: Scarcity, dependence and impacts on the economy. The case of andalusia. Estud. Econ. Apl. 2010, 28, 423-446.

21. Maestu, J.; Gomez, C.M.; Gutierrez, C. Los Usos del Agua en la economia Espanola: Situacion y Perspectivas; Ministerio de Medio Ambiente Medio Rural y Marino: Madrid, Spain, 2008. (in Spanish)

22. Duarte, R.; Sanchez-Choliz, J.; Bielsa, J. Water use in the spanish economy: An input-output approach. Ecol. Econ. 2002, 43, 71-85.

23. Velazquez, E. An input-output model of water consumption: Analysingintersectoral water relationships in Andalusia. Ecol. Econ. 2006, 56, 226-240.

24. Perez, C.D.; Gomez, C.M.; Del Villar, A. Water Uncertainty in Agriculture: An Application to Guadalquivir and Segura River Basins. Estud. Econ. Apl. 2011, 29, 333-358. (in Spanish)

25. Gonzalez, J.F. Assessing the macroeconomic impact of water supply restrictions through an input-output analysis. Water Resour. Manag. 2011, 25, 2335-2347.

26. Tirado, D.; Gomez, C.M.; Lozano, J. Un modelo de equilibrio general aplicado a Baleares: Análisis económico de la reasignación del agua para uso agrícola. Rev. Esp. Estudios Agrosoc. Pesq. 2006, 209, 75-109. (in Spanish)

27. Llop, M. Economic impact of alternative water policy scenarios in the Spanish production system: An input-output analysis. Ecol. Econ. 2008, 68, 288-294.

28. Lenzen, M. Aggregation versus disaggregation in input-output analysis of the environment. Econ. Syst. Res. 2011, 23, 73-89.

29. Strasser, G. Zur Bestimmung strategischer Sektoren mit Hilfe von Input-Output-Modellen. Jahrb. Natl. Stat. 1968, 182, 211-215.

30. Cella, G. The input-output measurement of interindustry linkages. Oxford B Econ. Stat. 1984, 46, $73-84$.

31. IO tables in are usually made available with a with a 4-5 years delay (the last year for the CL Region is 2008). Environmental accounting such as the Water Satellite Accounts may experience even larger delays (the last year available is 2006). 
32. Guerra, A.-I.; Sancho, F. Measuring energy linkages with the hypothetical extraction method: An application to Spain. Energy Econ. 2010, 32, 831-837.

33. Eurostat. Eurostat: Regional Statistics; European Commission: Bruxelles, Belgium, 2011. Available online: http://epp.eurostat.ec.europa.eu/portal/page/portal/region_cities/regional_statistics (accessed on 25 February 2013).

34. Duero River Basin Authority (DRBA). Proyecto de Plan Hidrológico de Cuenca; Duero River Basin Authority: Valladolid, Spain, 2012. (in Spanish)

35. Instituto Nacional de Estadistica (INE). Agrarian Census 2009; Instituto Nacional de Estadistica: Madrid, Spain, 2011. (in Spanish)

36. Duero River Basin Authority (DRBA). Plan Especial de Actuación en Situaciones de Alerta y Eventual Sequí; Duero River Basin Authority: Valladolid, Spain, 2007. (in Spanish)

37. Intergovernmental Panel on Climate Change (IPCC). Climate Change 2007: Impacts, Adaptation and Vulnerability. IPCC Fourth Assessment Report (AR 4); Contribution of Working Group II to the Fourth Assessment Report of the Intergovernmental Panel on Climate Change; Cambridge University Press: Cambridge, UK, 2007.

38. Hirschman, A.O. The Strategy of Economic Development (A Western Encore Edition); Yale University Press: New Haven, CT, USA, 1988.

39. The total output of each sector in the vector $x x$ equals the intermediate output (Ax) plus final demand (or alternatively, the final output, $y y$ ).

40. Instituto Nacional de Estadistica (INE). Water Satellite Accounts, Series 2000-2006. Available online: http:/www.ine.es/jaxi/menu.do? $\mathrm{L}=0 \&$ type $=$ pcaxis \&path=\%2Ft $26 \% 2 \mathrm{Fp} 067 \&$ file=inebase (accessed on 25 February 2013).

41. Junta de Castilla y Leon (JCYL). Tablas Input Output de Castilla y León. Available online: http://www.jcyl.es/web/jcyl/Estadistica/es/Plantilla100/1164898806585/1246989275272/__ (accessed on 25 February 2013). (in Spanish)

42. Lopez-Gunn, E.; Zorrilla, P.; Prieto, F.; Llamas, M.R. Lost in translation? Water efficiency in spanish agriculture. Agric. Water Manag. 2012, 108, 83-95.

43. This model uses constant prices and therefore avoids the effect of inflated prices in this sector.

44. Verdoorn, P.J. Fattori che regolano lo sviluppo della produtività del lavoro. L'industria 1949, 1, 3-10. (in Italian)

45. Kaldor, N. Causes of the Low Rate of Economic Growth of the UK: An Inaugural Lecture; Cambridge University Press: Cambridge, UK, 1966.

46. Gomez, C.M.; Perez, C.D. Do drought management plans reduce drought risk? A risk assessment model for a Mediterranean river basin. Ecol. Econ. 2012, 76, 42-48.

47. Ministerio de Agricultura, Alimentación y Medio Ambiente (MAGRAMA). Plan Nacional de Regadios. Available online: http://www.magrama.gob.es/es/agua/temas/gestion-sostenible-deregadios/plan-nacional-de-regadios/texto-completo/ (accessed on 30 September 2013). (in Spanish)

48. Ward, F.A.; Pulido-Velazquez, M. Water conservation in irrigation can increase water use. PNAS 2008, 105, 18215-18220.

49. Adamson, D.; Loch, A. Possible negative feedbacks from "gold-plating" irrigation infrastructure. Agric. Water Manag. 2014, in press. 
50. Quiggin, J. Why the guide to the proposed basin plan failed, and what can be done to fix it. In Water Policy Reform; Edward Elgar Publishing: Cheltenham, Australia, 2012; pp. 37-48.

51. Crase, L. Water markets, property rights and managing environmental water reserves. In Water Policy Reform; Edward Elgar Publishing: Cheltenham, Australia, 2012; pp. 49-62.

52. Gómez, C.M.; Delacámara, G.; Pérez-Blanco, C.D.; Ibáñez, E.; Rodríguez, M. Droughts and Water Scarcity-Tagus (Central Spain \& Portugal) and Segura (SE Spain) Interconnected River Basins (Deliverable No. 4.3); Work Package 4-Ex-Ante Case Studies. 7th Framework Contract Project EPI-Water Project (GA 265213); European Commission: Brussels, Belguim, 2013.

53. Organisation for Economic Co-operation and Development (OECD). Water Security for Better Lives. OECD: Paris, France, 2013.

54. McCann, L. Transaction costs and environmental policy design. Ecol. Econ. 2013, 88, 253-262.

55. Pannell, D.J.; Roberts, A.M.; Park, G.; Alexander, J. Improving environmental decisions: A transaction-costs story. Ecol. Econ. 2013, 88, 244-252.

56. Calzadilla, A.; Rehdanz, K.; Tol, R.S.J. The economic impact of more sustainable water use in agriculture: A computable general equilibrium analysis. J. Hydrol. 2010, 384, 292-305.

(C) 2014 by the authors; licensee MDPI, Basel, Switzerland. This article is an open access article distributed under the terms and conditions of the Creative Commons Attribution license (http://creativecommons.org/licenses/by/3.0/). 